\section{KING BAYINNAUNG AS HISTORICAL HERO IN THAI PERSPECTIVE}

\section{Sunait Chutintharanond ${ }^{1}$}

In the Burmese historical and literary context, King Bayinnaung has long been recognized as an exceptionally great king, who, after the fall of the Pagan Kingdom in the $13^{\text {th }}$ century, successfully reconstructed the second Burmese Kingdom. ${ }^{2}$ The greatness of King Bayinnaung is interestingly portrayed in local Burmese historical writings, such as The Ketummadi Toungoo Chronicle ${ }^{3}$ and in nationally known chronicles such as the U Kala Chronicle and The Hmannan or The Glass Palace Chronicle. Stories concerning the glory of the king are also found in various types of Burmese poetic works, for instance Maw-gun composed, as a rule, to commemorate some memorable event. ${ }^{4}$ Naung-yo-ti-pyo Maw-gun, for example, was written to commemorate the great victory of Bayinnaung over the Pyi (Prome) army in 1542 A.D. This battle was then known as the Naung-yo Battle. ${ }^{5}$ It is evident that after the battle, Tabinshweti, the King of Toungoo at that time, gave him the honorific title of

${ }^{1}$ Lecturer, Department of History

Faculty of Arts, Chulalongkorn University

${ }^{2}$ Myan-Ma-Swe-Zon-Kyan, vol. 8 (Rangoon, 1963), p. 307.

${ }^{3}$ Saya Sein Lwin Lae, Mintaya Shwee Hti hnin Buyin Naung (Rangoon: Modern Publishing House, 1968), p. 345.

4 "Bayinnaung in Burmese Literature".

5 Saya Sein Lwin Lae, pp. 221-27.
"Bayinnaung", meaning 'The King's brother'. ${ }^{6}$

King Bayinnaung has also been recognized in Thai society as a cakravartin king or a Legendary Universal Monarch. Ayudhya chronicles revised after the fall of Ayudhya in 1767 , for example, describe the wars waged by King Bayinnaung against Ayudhya on various occasions (1563 and 1569 A.D.) as wars led by an undefeatable king who could gain victory in ten directions or Phra Chao Chana Sib Thit. They recounted also how he aspired to be the Lord of the White Elephants. ${ }^{7}$ Even though this king was depicted by Thai scholars as an imperialistic expansionist and an enemy of the Thai nation ${ }^{8}$ during the nation building period in Thailand particularly in Prince Damrong Rajanubhab's famous historical writing "Our Wars with the Burmese" (Thai rop Phama), King Bayinnaung was later understood by the Thai people in general as a strong warrior and a great lover. This fanciful and memorable image was invented by a famous novelist named Mr. Chot Phraephan, or

\footnotetext{
${ }^{6}$ Khin Maung Nyunt, "King Bayint Naung's Place 'Kamboza Thadi"' in The New Light of Myanmar, Sunday, 12 September 1993.

7 Phraratchapongsawadan Krung Sri Ayudhya chabap Phanchantanumat (Choem) kup Chakkraphatdipong (Chat) Bangkok: Krung Wittaya, 1964), pp. 64-79.

${ }^{8}$ Prince Damrong Rajanubhab, Phongsawadan ruang Thai rop Phama, lem 1 (1928), p. 42.
} 
Yakhob (his pen name) in his interesting and rousing novel, entitled $A$ Man Who Gained Victory in Ten Directions (Phu Chana Sib Thit). The image of King Bayinnaung created by Yakhob has since become the most famous and influential in Thai society.

With regard to the heroic image of King Bayinnaung as a Universal Monarch in Thai perception and Thai historical writings, it is interesting that such an image was invented after the destruction of Ayudhya by the Burmese in 1767. Prior to that historical incident, neither King Bayinnaung nor other leading kings of Myanmar had received any special attention from Thai chronicle compilers. The Luang Prasert Chronicle of Ayudhya, compiled and written at the order of King Narai in 1680, for example, does not specifically glorify one of the most famous victories of King Bayinnaung over an Ayudhya King, Maha Chakraphat, in the War of the White Elephants in 1563. In contrast with the Thai chronicles compiled and revised after the defeat of Ayudhya in 1767, which vividly depict and extensively commemorate the victory of King Bayinnaung in the 1563 war, the Luang Prasert Chronicle provides only a very brief account concerning the War of the White Elephants:

In 925 (1563 A.D.), the year of the pig, Niphatr the King of Pegu (or Phra Chao Hongsa Nipantara Bayinnaung) raised an army in the $12^{\text {th }}$ month. On Sunday, the $5^{\text {th }}$ day of the $2^{\text {nd }}$ waning month, he conquered Phitsnulok. At that time there was a famine of rice and it was sold at the rate of 3 measures for one tical; many people also died of fever. The King of Pegu conquered all the northern states and then proceeded to Ayudhya. Then the King of Ayudhya asked for relations of friendship to be established, and the two kings thereupon swore an oath of fidelity at Wat Phra Meru. The King of Pegu then asked that the king's son and four white elephants be sent to Pegu. ${ }^{9}$

Unlike the Luang Prasert version, Ayudhya chronicles revised after the last fall of the capital in 1767 , describe and glorify the triumph of King Bayinnaung in the 1563 war at length. Phraratchapong sawadan Krung Sri Ayudhya Chabab Phanchantanumat (Choem), a chronicle of Ayudhya revised in 1795 in the reign of King Rama I, the founder of the Chakri Dynasty and the latest Thai capital, Bangkok, describes King Bayinnaung as the King of Hongsawady who ruled over Ramanadesa or the Mon kingdom and possessed great hpon--Merit and Power--that extended in ten directions. ${ }^{10}$ Furthermore, Thai chronicle compilers depicted the War of the White Elephants as a righteous campaign of an undefeatable king, who wished to obtain the white elephants which were a symbolic treasure of the Universal Monarch or the cakravartin. ${ }^{11}$ According to the royal chronicles, the cause of war and the subsequent subjugation of Ayudhya stemmed from the fact that the King of Ayudhya refused to send two white elephants to the court of Pegu upon the

9 O. Frankfurter, "Translation of 'Events in Ayudhya', 686-966" JSS, 6:3 (1909), p. 13.

${ }^{10}$ Phraratchapongsawadan Krung Sri Ayudhya chabap Phanchantanumat (Choem) kup Chakkraphatdipong (Chat), p. 65.

${ }^{11}$ Ibid., pp. 65-67. 
request of King Bayinnaung. ${ }^{12}$ The war between the King of Ayudhya and Bayinnaung, as a result, was not only a militaristic contest but also a symbolic ritual for political and religious supremacy in the tradition of Theravada Buddhist kings. The triumph of King Bayinnaung, without doubt, indicated that the merit and glory of the Burmese king that were superior to those of King Mahachakraphat of Ayudhya and his subjects. The Bangkok chroniclers interestingly describe how King Bayinnaung, in contending against his Ayudhya counterpart, claimed that his merit or hpon far surpassed that of his rival. For instance, the chronicle compilers put these words in the Burmese king's mouth when comparing his hpon to that of the Ayudhya monarch:

Naturally, those people with delusions did not realize their potential was like small birds and short-legged rabbits. The rabbit swam in the deep ocean believing that its legs could reach the bottom of the ocean. It then sank and died. As for the bird, it challenged a garuda to fly across the ocean. He very soon exhausted his energy and fell into the sea. ${ }^{13}$

The hidden meaning of the analogy drawn by Bangkok chroniclers does not contradict King Alaung-mintaya's (Alaungpaya, 1752-60) explanation of the downfall of the Nyaungyan dynasty: "When a man of hpon comes, the man without hpon disappears." 14

\footnotetext{
${ }^{12}$ Ibid., p. 67.

${ }^{13}$ Ibid., pp. 73, 74.

${ }^{14}$ Tun Aung Chain, "Legitimation Ploy in $18^{\text {th }}$ Century Burma," unpublished paper, p. 2.
}

King Bayinnaung, in the perception of the early Bangkok ruling class, was a great king whose virtues corresponded to the idea and image of a cakravartin raja, the Lord of the White Elephants and the King who is "the Conqueror in All Ten Directions." According to the Traibhumikatha, or the Three Worlds of King Ruang, a work of Thai classical literature describing the nature of the entire Buddhist Universe, the cakravartin king is inevitably escorted by a tremendous number of troops when on the march from the Jumbudipa continent to conquer the other three quarters of the human world: Purvavideha, Uttarakuru and Amaragoyana. The Traibhumikatha provides the following description:

One might wonder how great was the cakravatradhiraja King's entourage. Let it be known that a field 12 yojana wide with a circumference of 36 yojana could just fit in all the men, and there would be just enough room for the jewelled Wheel to remain therein. ${ }^{15}$

Interestingly, the army used by King Bayinnaung to attack Ayudhya is pictured by Bangkok chroniclers in the same way as the entourage of the cakravartin king in the Traibhumikatha and other religious texts copied and revised in the reign of King Rama I of Bangkok.

The King of Hongsawady was rich in royal ornament. He put on seven great golden shoulder laces, splenderous head covering and onyx-black suit for victory

\footnotetext{
${ }^{15}$ King Lithai, Traibumikatha: The Story of the Three Planes of Existence (Bangkok: Amarin Printing Group, 1985), p. 173.
} 
in combat. He then rode on his fighting elephant named Plaidevanaga-binaya, which was 6 sok ( 1 sok $=50$ centimeters), 1 kuep $(1$ kuep $=$ an outstretched hand or 25 centimeters) and 5 inches in height. The royal creature, in a splendid NagaIndra robe ornamented with seven kinds of precious stones, was guarded by dignified armed forces, horsemen and royal aidesde-camp in immeasurable number. The whole army, well-equipped with weapons, ammunitions, flags and long-poled umbrellas, moved in extensive lines, creating an image of the king's legion as a marvelous wave. It was also thronged with ranking ministers and warriors in rows forming military processions in all directions--left \& right and front \& rear. When the auspicious moment arrived, the purohita blew his horn made from a conch and struck his gong and drum, making a loud noise. The King then marched the regiment out of the capital city of Hongsawady. ${ }^{16}$

According to several Thai chronicles, the total number of King Bayinnaung's fighting men reached 900,000 . "The combined noise of the soldiers, elephants and horses was like the sound of a heavy storm." "17

The attempt of early Bangkok chronicle compilers in depicting King Bayinnaung as a cakravartin king, however, does not emerge without any historical and cultural sources. The history and legend regarding the glory of this great king was mentioned in the vernacular historical literature of Theravada Buddhist kingdoms in

\footnotetext{
${ }^{16}$ Phraratchapongsawadan Krung Sri Ayudhya chabap Phanchantanumat (Choem) kup Chakkraphatdipong (Chat), pp. 68-69.

${ }^{17}$ Ibid., pp. 68, 71.
}

mainland Southeast Asia stretching from the Irrawaddy to the Mekong River-basin.

The Mon inscription on Bayinnaung's bronze bell at Shwezigon (June 1557), for example, glorifies the King as follows:

His Majesty Sri Parama Maha Dhamma-rajadhiraja, Lord of Ketumati (Toungoo), Hanmsawati (P e g u ) S a r e k he t t a r a (Thayekhittaya), Arimaddanapura (Pagan), Ava (Inn-wa), Moe Mit, Sibaw, Moe Gaung, Moe Hnyin and Kale, was the zenith of the king of kings, having so many sets of white umbrellas. ${ }^{18}$

The Hantawaddy Hsinbyumyashin Ayedawpon, or An Account of the King of the White Elephants of Hantawaddy, also refers to King Bayinnaung as the Lord of Water and Earth, the King of the Golden Palace, the King of the White Elephants and the Lord of the Mines of Rubies, Gold and Silver. ${ }^{19}$ Without doubt, the author of this ayedawpon, Lewenawratha, was influenced by the vision of an ideal Buddhist world ruler, the cakravartin; accordingly, he then commemorated the achievements of King Bayinnaung with the cakravartin norm and charismatic glory.

It is obvious that the same patterns of glorification are also found in historical literature of the neighboring states, for example, the Raman Chronicle, the Cambodian Chronicle and the Yodaya

\footnotetext{
${ }^{18}$ Nai Pan Hla, "Translation of Mon Inscription of Bayinnaung's Bronze Bell at Shwezigon" unpublished papers, p. 4. 19 "Hantawadi Hsinbyushin Ayedawpon" in Ayedawpon (6) Saung Twe Myanmaminmya Ayedawpon (Rangoon, 1970), p. 321.
} 
Yazawin, known in Thai as the "Testimony of the People of the Old Capital, Ayudhya."

The image of King Bayinnaung as a Universal Monarch is interestingly described in a Mon chronicle translated into Thai at the order of King Mongkut of Bangkok. According to the chronicle, King Bayinnaung was named Phrachao Farangmangtri, an honorific that probably derives from the word Bayin-min-gyi meaning the Great King. "The king has a great deal of power, white elephants, and mines of jewels, gold and silver. He has also gained victory over all kings in several countries and is the greatest ruler of the four states namely, Ramanadesa, Pagandesa (the whole kingdom of Burma), Siamdesa and Laodesa. As a result, the Raman people have given Phrachao Farangmangtri the splendrous title Täla Ñah Jamnah Duih Cah, which signifies 'His Majesty the Conqueror of the Ten Directions." 20 Since the concept of the conqueror in all ten directions has never been emphasized either in the Burmese or Thai tradition of written history about the glory of King Bayinnaung, it is possible that Bangkok chroniclers adopted and adapted the concept from the Mon ruling class, who had continuously fled to seek shelter in the Kingdom of Ayudhya, Thonburi and Bangkok respectively after Rangoon and Hantawaddy were attacked and overcome by King Alaungmintaya.

Myth regarding the religious and military might of King Bayinnaung had long been implanted in the memory of the Ayudhya

\footnotetext{
${ }^{20}$ Phongsawadan Phamaraman in Prachum Phongsawadan chabap Hosamuthangchat lem 1 (Bangkok: Kaona, 1963), p. 305; Nai Pan $\mathrm{Hla}$, personal correspondence (18 January 1994).
}

people. Originally the testimony of Ayudhya's war captives brought back to Ava after the 1767 defeat reveals that Bayinnaung was a devoted patron of the religion of the Lord Buddha. For example, he donated valuable treasures especially the bronze statues obtained from the Royal Temple in the Grand Palace of Ayudhya, Wat Phrasrisanphet, to the Mahamuni Buddha image housed in Arakan. The Yazawin describes the religious role of King Bayinnaung as follows:

As for the King of Hongsa, as time passed by, he had learned that there existed the Mahamuni Buddha Image housed in the country of Great Myanmar called "Yakai". The Buddha Image was molded since the time the Lord Buddha still existed. The image has tremendous miraculous Buddhist power. ... The King, with strong faith in the Mahamuni, therefore, arranged a number of articles of worship such as ornamental cloth, three saffron golden candles, pop-rice and golden flowers, umbrellas and golden flags, as well as the twelve images of the zodiac which the King of Hongsa brought in part from the City of Ayudhya such as the images of human beings, the Erawan Elephant (the Lord Indra's vehicle), a lion, a leoelephant, a Manusingha (half human-half lion), a singha, and a garuda. These bronze statues and the innumerable articles of worship were propitiated by the King of Hongsa, then he held a great celebration and poured the water of donation. He thereafter 
summoned the ministers to arrange for the articles of worship to be loaded into a junk for the purpose of contribution to Mahamuni at the City of Yakai in A.D. $1568 .^{21}$

In conclusion, Bayinnaung was never an unknown king in the historical context of Southeast Asia and especially in the oral tradition of the Ayudhya citizen. Nevertheless, that the myth of Bayinnaung was dramatically reconstructed by the Thai ruling class in the royal chronicles revised upon the command of Thai kings was unconventional. What is the actual reason underlying this historiographical mission?

The sack of Ayudhya in the second half of the eighteenth century was totally different from the attacks in 1563 and 1569. Prince Damrong in his Our Wars with the Burmese states that "the expedition led by the King of Hongsawady (Bayinnaung) and the one carried out by the King of Ava (Hsinbyushin) are not the same ... The primary purpose of the former in attacking Ayudhya was to reduce the Thai to vassalage and to expand his kingdom in the manner of a king of kings (Rachathirat or Rajadhiraja), whereas the major aim of the latter was just to loot the city and take away war prisoners. Thus, in the last attack, the Burmese, with no intention of retaining Ayudhya as their client state, burnt all big and small cities they captured, including the capital, down to ashes. The defeat on this occasion thus brought extreme havoc to the kingdom of

${ }^{21}$ Kamhaikan Khunluanghawat chabap Luang (Bangkok, 1916), pp. 3, 4.
Ayudhya, unlike when it had been seized by the King of Hongsawady." 22

The collapse of Ayudhya in 1767 not only impelled the Thonburi and early Bangkok rulers to reinvestigate and improve their military arts, but also forced them to create for themselves an acceptable status of leadership corresponding to the Buddhist standards namely, dharmaraja, bodhisatva and cakravartin. Like Bayinnaung, the founders of the Thonburi and Bangkok dynasty had no royal blood in their lineage; as a result, they had to legitimize their ruling position in accordance with Buddhist political norms and ideas of righteousness. It is under this tension that the myth and history concerning the might of King Bayinnaung were officially reconstructed and colorfully portrayed in Thai royal chronicles compiled and written after the sack of Ayudhya in 1767.

The Thonburi and early Bangkok rulers aimed to draw back King Bayinnaung's image to their realities in order to legitimize their succession to the throne. It would be wrong to conclude that in the perception of the Thai rulers after the fall of Ayudhya in 1767, King Bayinnaung was merely a king of Myanmar who successfully suppressed the Ayudhya kingdom. Unlike other foreign kings, Bayinnaung, was a proper symbol of the cakravartin, the typical Buddhist king of kings whose style and image they tried to assimilate. The concept of the cakravartin is universal from the beginning. It crosses over the border line of culture and nationality. In this respect, Thai kings

\footnotetext{
${ }^{22}$ Prince Damrong Rajanubhab,
} Phongsawadan ruang Thai rop Phama, lem 2, p. 1 . 
took as their model of kingship the great Bayinnaung, who in the indigenous historical writings could reunite his disintegrated kingdom and extend his tributary network, incorporating principalities which the Thai kings themselves aimed to reconquer after establishing new centers at Thonburi and Bangkok.

The creation of Bayinnaung's image as a cakravartin king in Thai historical writings after the collapse of Ayudhya was a deliberate, not an accidental happening. It is quite obviously a product of profound and significant change within the sociopolitical structure of the Thai state after the annihilation of the old capital in 1767. The image of Bayinnaung as a universal king did not last over a century. During the time when the sovereignty of the Thai kingdom was threatened by the expansion of the Colonial Powers, the Thai rulers of the early modernizing period brought in a totally new image of King Bayinnaung. $\mathrm{He}$ was characterized as an imperialistic expansionist and an enemy of the Thai nation. Nevertheless, King Bayinnaung later on was understood by Thai citizens as a talented military general and particularly as a man who had great success with women. This charming image was created by Mr. Chot Phraephan, or Yakhob, in his enthusiastic historical novel named $A$ Man Who Gained Victory in Ten Directions (1926). This last image of King Bayinnaung --a man who possesses a very delightful and attractive character--still remains in the perception and memory of Thai people. Nevertheless, Bayinnaung in Yakhob's imagination is no longer a great king of Myanmar; he is a commoner whose character appeals to the dreams and expectations of the Thais.

\section{References}

Damrong Rajanubhab, Prince. 1928. Phongsawadan ruang Thai rop Phama, lem 1.

Frankfurter, O. 1909. Translation of 'Events in Ayudhya', 686-966. In JSS 6:3.

Hantawadi Hsinbyushin Ayedawpon. 1970. In Ayedowpon (6) Saung Twe Myanmaminmya. Rangoon.

Kamhaikan Khunluanghawat chabap Luang. 1916. Bangkok.

Khin Maung Nyunt. 1993. King Bayint Naung's Palace 'Kamboza Thadi'. In The New Light of Myanmar. Rangoon.

Lithai, King. 1985. Traibumikatha: The Story of the Three Planes of Existence. Bangkok: Amarin Printing Group.

Myan-Ma-Swe-Zon-Kyan, vol. 8. 1963. Rangoon.

Phongsawadan Phamaraman. 1963. In Prachum Phongsawadan chabap Hosamuthangchat, lem 1. Bangkok: Kaona.

Phraratchapongsawadan Krung Sri Ayudhya chabap Phanchantanumat (Choem) kup Chakkraphatdipong (Chat). 1964. Bangkok: Krung Wittaya.

Saya Sein Lwin Lae. 1968. Mintaya Shwee Hti hnin Bayin Naung. Rangoon: Modern Publishing House. 